Article

\title{
Carboxylative Suzuki coupling reactions of benzyl chlorides with allyl pinacolborate catalyzed by palladium nanoparticles
}

\author{
Jian Sun a,\$, Jiasheng Wang a,b, Xiujuan Feng a,*, Yoshinori Yamamoto a,c,d, \\ Abdulrahman I. Almansour e, Natarajan Arumugam e, Raju Suresh Kumare, Ming Bao a,b,\# \\ a State Key Laboratory of Fine Chemicals, Dalian University of Technology, Dalian 116023, Liaoning, China \\ b School of Petroleum and Chemical Engineering, Dalian University of Technology, Panjin 124221, Liaoning, China \\ c Department of Chemistry, Graduate School of Science, Tohoku University, Sendai 980-8578, Japan \\ d Research Organization of Science and Technology, Ritsumeikan University, Kusatsu, Shiga 525-8577, Japan \\ e Department of Chemistry, College of Sciences, King Saud University, P.O. Box 2455, Riyadh 11451, Saudi Arabia
}

\section{A R T I C L E I N F O}

\section{Article history:}

Received 15 January 2018

Accepted 5 February 2018

Published 5 July 2018

\section{Keywords:}

Palladium nanoparticles

Carboxylative Suzuki coupling

Carbon dioxide

Benzyl chlorides

Allyl pinacolborate

\section{A B S T R A C $\mathrm{T}$}

Palladium-catalyzed carboxylative Suzuki coupling reactions of benzyl chlorides with allyl pinacolborate were successfully conducted in the absence of any extra ligand to produce $\beta, \gamma$-unsaturated esters in satisfactory to good yields. The carboxylative Suzuki coupling reaction proceeded smoothly under mild conditions in the presence of palladium nanoparticles generated in situ through the formation of a $\pi$-benzylpalladium chloride intermediate.

(C) 2018, Dalian Institute of Chemical Physics, Chinese Academy of Sciences. Published by Elsevier B.V. All rights reserved.

\section{Introduction}

$\mathrm{CO}_{2}$ is abundant, inexpensive, nontoxic, and environmentally benign; thus, its chemical fixation and transformation into valuable chemicals that involve new carbon-carbon bond formation has attracted considerable attention [1-6]. In general, strong nucleophilic organometallic reagents (i.e., metal $=$ lithium [7], magnesium [8], aluminum [9,10], or zinc [11-14]) directly undergo a reaction with $\mathrm{CO}_{2}$ to produce carboxyl-containing organic compounds. However, current methods for these reactions are limited with respect to functional group tolerance and substrate stability. In contrast to strong nucleophilic organometallic reagents, weak nucleophilic organometallic reagents (i.e., metal = tin [15], silicon [16], or boron [17]) cannot undergo a direct reaction with $\mathrm{CO}_{2}$ and require the presence of transition-metal catalysts for carboxylation. Among these organometallic reagents, organoboranes are frequently utilized because of their commercial availability, relatively low toxicity, and high tolerance to functional groups. Recently, Hazari et al. [18] reported a type of monodentate carboxylate

\footnotetext{
* Corresponding author. Tel: +86-411-84986180; Fax: +86-411-84986181; E-mail: fengxiujuan@dlut.edu.cn

\# Corresponding author. Tel: +86-411-84986180; Fax: +86-411-84986181; E-mail: mingbao@dlut.edu.cn

\$Present address: Institute of Petrochemical Technology, Jilin Institute of Chemical Technology, Jilin 132022, Jilin, China.

This work was supported by the National Natural Science Foundation of China (21372035, 21373041, 21773021), the Fundamental Research Funds for the Central Universities (DUT17ZD212), and the International Scientific Partnership Program ISPP at King Saud University for funding this research work through ISPP\#0048.

DOI: 10.1016/S1872-2067(18)63045-1 | http://www.sciencedirect.com/science/journal/18722067 | Chin. J. Catal., Vol. 39, No. 7, July 2018
} 
[( $\eta^{3}$-allyl)Pd(L)(carboxylate) $\left.(\mathrm{L}=\mathrm{NHC})\right]$, which is an efficient catalyst for the carboxylation of allylboranes with $\mathrm{CO}_{2}$. Then, they developed an $\mathrm{N}$-heterocyclic carbene-supported dimer as an active and stable catalyst for the carboxylation of allylboranes with $\mathrm{CO}_{2}$ (Eq. (1)) [19]. Duong et al. [20] also studied the carboxylative reaction of allylboronates with $\mathrm{CO}_{2}$ in the presence of a $\mathrm{Cu}(\mathrm{I}) / \mathrm{NHC}$ catalyst (Eq. (2)). The abovementioned $\mathrm{Pd}$ - or $\mathrm{Cu}$-catalyzed carboxylation reactions of allylboranes involved the use of $N$-heterocyclic carbene ligands. The use of carbene ligands is typically disadvantageous because it often leads to air/moisture sensitivity, tedious work-up procedures, and high work-up costs [21-27]. Therefore, the development of a simple and robust catalyst system that allows for the efficient carboxylation of allylboranes with $\mathrm{CO}_{2}$ without any additional ligands is desirable.

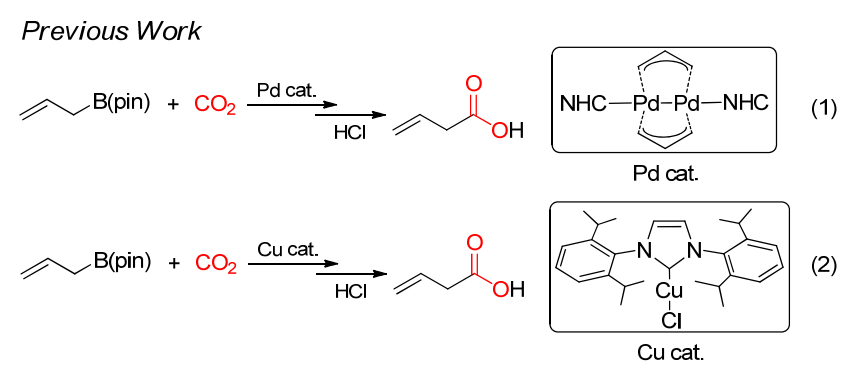

This Work

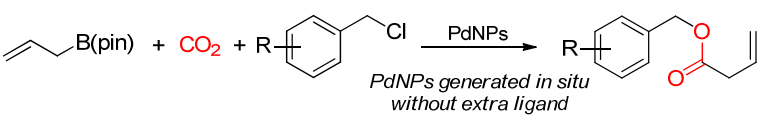

Recently, our group reported palladium nanoparticles-catalyzed carbonylative and carboxylative reactions of (chloromethyl)arenes with allyltributylstannane [28-30]. We found that palladium nanoparticles can form in situ, and $\pi$-benzyl- $\pi$-allyl could be used as the carbon-based ligand for palladium nanoparticles [31-33]. Based on our previous study, we hypothesized that the $\pi$-allyl involving allylboranes may also be used as a carbon-based ligand for the palladium-catalyzed chemical fixation of $\mathrm{CO}_{2}$. As expected, the carboxylative Suzuki coupling reaction of benzyl chlorides with allyl pinacolborate occurred in the presence of palladium nanoparticles (PdNPs) (Eq. (3)). The results are reported in the current work.

\section{Experimental}

All reactions were carried out under a nitrogen atmosphere, unless otherwise noted. The solvents used were purified by standard techniques without special instructions. ${ }^{1} \mathrm{H}$ and ${ }^{13} \mathrm{C}$ NMR spectra were recorded on either a Varian Inova-400 spectrometer (400 MHz for ${ }^{1} \mathrm{H}$ and $100 \mathrm{MHz}$ for ${ }^{13} \mathrm{C}$ ) or a Bruker Avance II-400 spectrometer (400 MHz for ${ }^{1} \mathrm{H}$ and 100 $\mathrm{MHz}$ for ${ }^{13} \mathrm{C}$ ). $\mathrm{CDCl}_{3}$ and tetramethylsilane were used as a solvent and internal standard, respectively. Infrared spectra were recorded on a NEXUS Fourier transform-infrared spectrometer. High-resolution mass spectra were recorded through gas chromatography-time-of-flight mass spectrometry. All starting materials are commercially available.

\section{Results and discussion}

In the initial study, the reaction of benzyl chloride (1a) with allyl pinacolborate in the presence of $\mathrm{CO}_{2}$ was selected as a model for the optimization of reaction conditions (Table 1). A series of palladium precatalysts, including $\mathrm{PdCl}_{2}, \mathrm{Pd}_{2}(\mathrm{dba})_{3}$, $\mathrm{Pd}(\mathrm{OAc})_{2}$, and $\mathrm{Pd}(\mathrm{acac})_{2}$, were initially tested in tetrahydrofuran (THF) at $50^{\circ} \mathrm{C}$ by using TBAB and $\mathrm{KF}$ as a stabilizer and an activator, respectively (Table 1 entries 1-4). Among the palladium precatalysts tested, $\mathrm{Pd}(\mathrm{acac})_{2}$ exhibited the highest catalytic activity, affording the benzyl but-3-enoate (2a) in $81 \%$ yield (Table 1 entry 4). These results indicated that PdNPs generated in situ from newly formed $\operatorname{Pd}(0)$ species possessed higher catalytic activity than those generated from $\mathrm{Pd}_{2}(\mathrm{dba})_{3}$. No reaction was observed when TBAB was used as a stabilizer in the absence of $\mathrm{KF}$, suggesting that the target reaction was unable to proceed in the absence of an activator (Table 1 entry 5) [34]. Thus, we screened several fluorides (KF, TBAF, and $\mathrm{CsF}$ ) to determine a suitable activator (Table 1 entries 4,6 , and 7). The mixed products of $\mathbf{2 a}$ and $\mathbf{2} \mathbf{a}^{\prime}$ were obtained in $53 \%$ yield when TBAF was used as the activator for the reaction (Table 1 entry 6), and only a 13\% yield of 2 a was obtained when $\mathrm{CsF}$ was used as the activator (Table 1 entry 7). These results indicated that $\mathrm{KF}$ is the most suitable activator for the carboxylative Suzuki coupling of benzyl chlorides with allyl pinacolborate. Nonpolar (toluene) and polar [THF, dioxane, and $\mathrm{N}, \mathrm{N}$-dimethyl formamide (DMF)] solvents were then examined (Table 1 entries 4 vs. 8-10). THF was the best solvent. The yield of $\mathbf{2 a}$ decreased to $33 \%$ when the reaction was performed for $12 \mathrm{~h}$ (Table 1 entry 11). Further studies revealed that no product was generated when the reaction was performed at room temperature (Table 1 entry 12). A similar yield of product $\mathbf{2 a}$

\section{Table 1}

Reaction condition screening a.

\begin{tabular}{|c|c|c|c|c|}
\hline Entry & Catalyst & Activator & Solvent & Yield ${ }^{\mathrm{b}}(\%)$ \\
\hline 1 & $\mathrm{PdCl}_{2}$ & $\mathrm{KF}$ & THF & 37 \\
\hline 2 & $\mathrm{Pd}_{2}(\mathrm{dba})_{3}$ & KF & THF & 71 \\
\hline 3 & $\mathrm{Pd}(\mathrm{OAc})_{2}$ & $\mathrm{KF}$ & THF & 50 \\
\hline 4 & $\operatorname{Pd}(\mathrm{acac})_{2}$ & $\mathrm{KF}$ & THF & 81 \\
\hline 5 & $\operatorname{Pd}(\mathrm{acac})_{2}$ & None & THF & 0 \\
\hline $6^{c}$ & $\operatorname{Pd}(\mathrm{acac})_{2}$ & TBAF & THF & 53 \\
\hline 7 & $\operatorname{Pd}(\mathrm{acac})_{2}$ & CsF & THF & 13 \\
\hline 8 & $\operatorname{Pd}(\mathrm{acac})_{2}$ & $\mathrm{KF}$ & Toluene & 22 \\
\hline 9 & $\operatorname{Pd}(\text { acac })_{2}$ & $\mathrm{KF}$ & Dioxane & 67 \\
\hline 10 & $\operatorname{Pd}(\mathrm{acac})_{2}$ & KF & DMF & 29 \\
\hline $11^{\mathrm{d}}$ & $\operatorname{Pd}(\mathrm{acac})_{2}$ & KF & THF & 33 \\
\hline $12 \mathrm{e}$ & $\operatorname{Pd}(\mathrm{acac})_{2}$ & $\mathrm{KF}$ & THF & 0 \\
\hline $13^{\mathrm{f}}$ & $\operatorname{Pd}(\mathrm{acac})_{2}$ & KF & THF & 80 \\
\hline $14 \mathrm{~g}$ & $\mathrm{Pd}(\mathrm{acac})_{2}$ & KF & THF & 76 \\
\hline
\end{tabular}

a Reaction conditions: benzyl chloride (1a, $0.5 \mathrm{mmol}$ ), allyl pinacolborate $(0.6 \mathrm{mmol}), \mathrm{CO}_{2}(2.0 \mathrm{MPa})$, a Pd catalyst $(5 \mathrm{~mol} \%)$, a stabilizer TBAB (1.4 equiv.), a fluoride activator (2.0 equiv.), and a solvent $(5 \mathrm{~mL}$ ) at $50{ }^{\circ} \mathrm{C}$ for $24 \mathrm{~h}$. ${ }^{\mathrm{b}}$ Isolated yield. c A mixture of products $\mathbf{2 a}$ and $\mathbf{2 a} \mathbf{a}^{\prime}$ was obtained. ${ }^{\mathrm{a}}$ The reaction was performed for $12 \mathrm{~h}$. e The reaction was performed at room temperature. ${ }^{\mathrm{f}} \mathrm{The}$ reaction was performed at $70^{\circ} \mathrm{C}$. $\mathrm{g}$ The reaction was performed at $3.0 \mathrm{MPa}$ of $\mathrm{CO}_{2}$. 
was obtained when the reaction temperature was enhanced to $70{ }^{\circ} \mathrm{C}$, and a slightly decreased yield was obtained when the reaction was performed at $3.0 \mathrm{MPa} \mathrm{CO}_{2}$ (Table 1 entries 13 and 14). Therefore, the subsequent palladium-catalyzed carboxylative Suzuki coupling reactions of various benzyl chlorides with allyl pinacolborate were performed in the presence of $\mathrm{Pd}(\mathrm{acac})_{2}$ as a precatalyst, TBAB as a stabilizer, and $\mathrm{KF}$ as an activator at $50{ }^{\circ} \mathrm{C}$ and at $2.0 \mathrm{MPa}$ of $\mathrm{CO}_{2}$ pressure in THF for 24 h.

The carboxylative Suzuki coupling reactions of benzyl chlorides 1a-1m with allyl pinacolborate were conducted under optimum conditions, and the results are summarized in Table 2. Good yields similar to that of $\mathbf{2 a}$ were observed when the 1-(chloromethyl)-4-fluorobenzene (1b) bearing a fluorine at-

\section{Table 2}

Palladium-catalyzed carboxylative Suzuki coupling of benzyl chlorides with allyl pinacolborate a.

$$
\underset{1}{\mathrm{Ar}} \widehat{\mathrm{Cl}}+\mathrm{CO}_{2} \underset{\substack{\mathrm{TBAB}, \mathrm{KF}, \mathrm{THF} \\ 50^{\circ} \mathrm{C}, 24 \mathrm{~h}}}{\stackrel{\mathrm{Pd}(\mathrm{acac})_{2}(5 \mathrm{~mol} \%)}{\longrightarrow}} \mathrm{Cr}_{2}^{\mathrm{Cr}}
$$

\begin{tabular}{llll}
\hline Entry & Benzyl chloride $\mathbf{1}$ & Product $\mathbf{2}$ & Yield $^{\mathrm{b}}(\%)$ \\
\hline
\end{tabular}

1

2<smiles>C=COc1ccc(CCl)cc1</smiles><smiles>ClCc1cccc2ccccc12</smiles>

9<smiles>Cc1ccc2ccccc2c1CCl</smiles>

10<smiles>ClCc1cccs1</smiles>

$\mathbf{1 j}$

O

$1 c$

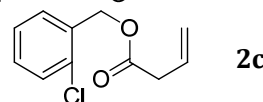

76

57

1d

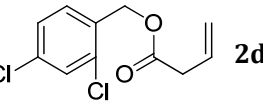

$1 \mathrm{e}$<smiles>C=CCC(=O)OCc1ccc(C)cc1</smiles>

16 舟

$1 \mathrm{~g}$

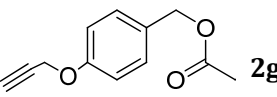

$1 \mathrm{~h}$<smiles>C=CCC(=O)OCc1cccc2ccccc12</smiles>

1i<smiles>C=CCC(=O)OCc1c(C)ccc2ccccc12</smiles><smiles>C=CCC(=O)OCc1cccs1</smiles>

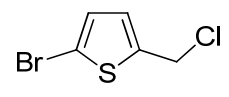

om on the para position of the benzene ring was employed under optimized reaction conditions. The desired product, 4-fluorobenzyl but-3-enoate (2b), was obtained in 76\% yield (Table 2 entry 2). Ortho-chloro-substituted benzyl chloride (1c) also underwent target carboxylative coupling and provided the desired product, 2-chlorobenzyl but-3-enoate (2c), in 57\% yield (Table 2 entry 3). However, only 49\% yield of 2,4-dichlorobenzyl but-3-enoate (2d) was obtained when 2,4-dichloro-1-(chloromethyl) benzene (1d) bearing two chlorine atoms on the ortho and para positions of the benzene ring was employed under optimized reaction conditions (Table 2 entry 4). Notably, halogen atoms ( $\mathrm{F}$ and $\mathrm{Cl}$ ) linked to the benzene rings of the substrates were maintained in the structures of the products $(\mathbf{2} \mathbf{b}-\mathbf{2 d})$, suggesting that further manipulation may produce useful compounds. Reactions of benzyl chlorides 1e-1g bearing methyl, methoxyl, and propargyloxy on the para positions generated comparatively good yields of products $\mathbf{3 e}$ to $3 \mathrm{~g}(73 \%, 71 \%$, and $63 \%$, respectively). Furthermore, 1-(chloromethyl)naphthalene (1h) and $o$-methyl-substituted 1-(chloromethyl)naphthalene $\mathbf{1 i}$ were utilized in this type of a carboxylative coupling reaction (Table 2 entries 8 and 9). Products $\mathbf{2 h}$ and $\mathbf{2 i}$ were obtained in moderate yields $(60 \%$ and $71 \%$, respectively).

The success in the carboxylative coupling of benzyl chlorides and 1-(chloromethyl)naphthalene substrates encouraged us to examine the carboxylative coupling reactions of five-membered heteroarene substrates (Table 2 entries 10 and 11). The reactions of 2-(chloromethyl) thiophene (1j) and 5-bromo-2-(chloromethyl)thiophene $(\mathbf{1 k})$ proceeded smoothly to furnish the corresponding $\beta, \gamma$-unsaturated ester products $\mathbf{2 j}$ and $\mathbf{2 k}$ in satisfatory yields ( $68 \%$ and $74 \%$, respectively). Finally, 1-(bromomethyl)naphthalene (11) and (E)-(3-chloroprop-1-en-1-yl)benzene (1m) were utilized in this type of carboxylative coupling reaction (Scheme 1). The desired products 2h and $\mathbf{2 m}$ were obtained in $58 \%$ and $44 \%$ yields, respectively. The relatively low yields were considered to be due to the low reactivities of $\mathbf{1 l}$ and $\mathbf{1 m}$; incomplete conversion of the starting materials was observed.

A plausible mechanism for the palladium nanoparticles-catalyzed carboxylative Suzuki coupling reaction of benzyl chlorides with allyl pinacolborate is illustrated in Scheme 2. The precatalyst $\mathrm{Pd}(\mathrm{acac})_{2}$ reacted with allyl pinacolborate in the presence of the stabilizer TBAB and the activator KF to generate PdNPs. The oxidative addition of benzyl chloride to PdNPs then occurred to produce a $\pi$-benzylpalladium chloride intermediate $\mathbf{A}$, which underwent transmetalation with allyl

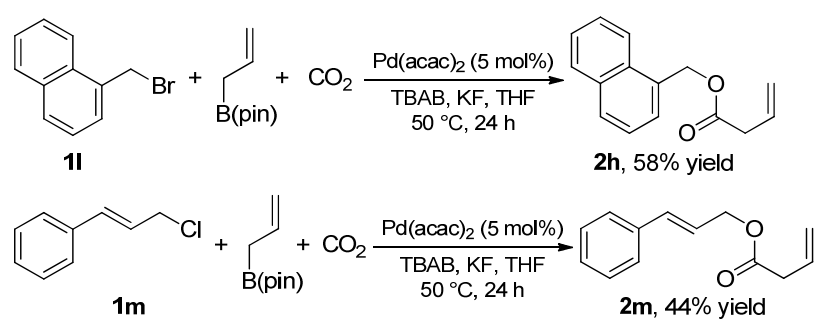

Scheme 1. Carboxylative Suzuki coupling reactions of 1-(bromomethyl)naphthalene and (E)-(3-chloroprop-1-en-1-yl) benzene with allyl pinacolborate. a Reaction conditions: benzyl chloride $(\mathbf{1}, 0.5 \mathrm{mmol})$, allyl pinacolborate ( $0.6 \mathrm{mmol}), \mathrm{CO}_{2}(2.0 \mathrm{MPa}), \mathrm{Pd}(\mathrm{acac})_{2}(5 \mathrm{~mol} \%)$, TBAB (1.4 equiv.), and $\mathrm{KF}\left(2.0\right.$ equiv.) in THF $(5 \mathrm{~mL})$ at $50^{\circ} \mathrm{C}$ for $24 \mathrm{~h}$. ${ }^{\mathrm{b}}$ Isolated yield. 


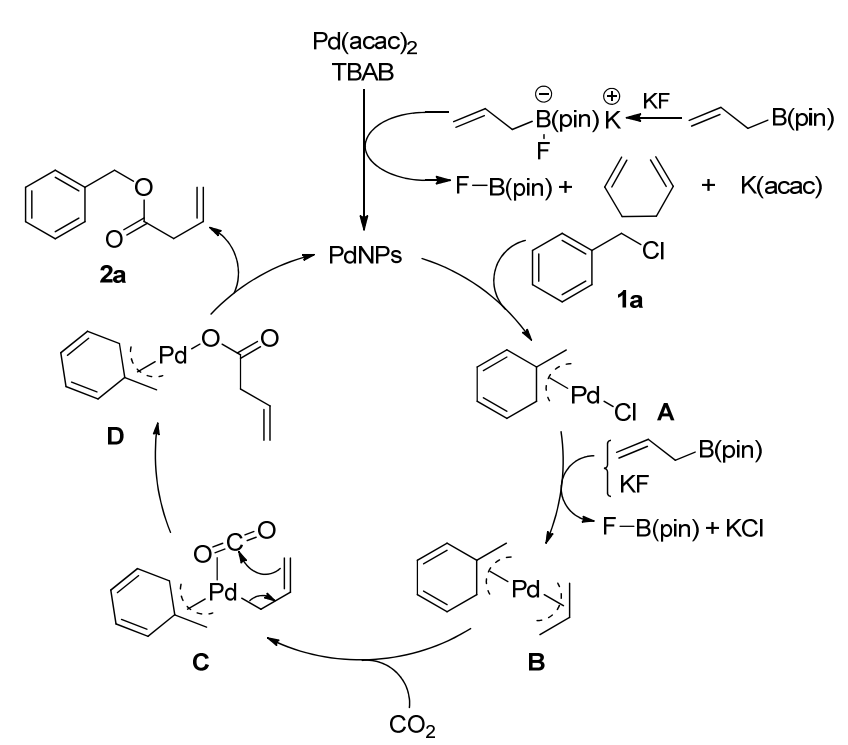

Scheme 2. The proposed mechanism for carboxylative Suzuki coupling reactions of benzyl chlorides with allyl pinacolborate.

pinacolborate in the presence of the activator $\mathrm{KF}$ to generate the $\pi$-benzyl- $\pi$-allylpalladium intermediate $\mathbf{B}$. The $\pi$-allyl carbon-based ligands in intermediate $\mathbf{B}$ facilitate the coordination of $\mathrm{CO}_{2}$ to form intermediate $\mathbf{C}$. The nucleophilic addition of the $\sigma$-allyl group to $\mathrm{CO}_{2}$ produced intermediate $\mathbf{D}$, which underwent reductive elimination to produce the target product $\mathbf{2 a}$ and regenerate PdNPs.

\section{Conclusions}

We developed a novel palladium nanoparticles-based catalyst system for carboxylative Suzuki coupling of benzyl chlorides with allyl pinacolborate in the absence of phosphine ligands. Notably, the catalytic system is generated in situ; thus, cumbersome processes for the preparation of metal nanoparticles can be prevented when this system is used. The mild reaction conditions (low $\mathrm{CO}_{2}$ pressure and temperature), experimental simplicity, and the broad substrate scope are features of the novel and general catalytic method proposed in this study. Further reactions and mechanistic studies are underway in our laboratory and will be reported in due course.

\section{References}

[1] T. Sakakura, J. C. Choi, H. Yasuda, Chem. Rev., 2007, 107, 2365-2387.

[2] A. Correa, R. Martín, Angew. Chem. Int. Ed., 2009, 48, 6201-6204.

[3] M. Mikkelsen, M. Jørgensen, F. C. Krebs, Energy Environ. Sci., 2010, 3, 43-81.

[4] K. Huang, C. L. Sun, Z. J. Shi, Chem. Soc. Rev., 2011, 40, 2435-2452.

[5] L. Ackermann, Angew. Chem. Int. Ed., 2011, 50, 3842-3844.

[6] Y. Tsuji, T. Fujihara, Chem. Commun., 2012, 48, 9956-9964.

[7] W. J. Yoo, M. G. Capdevila, X. W. Du, S. Kobayashi, Org. Lett., 2012, 14, 5326-5329.

[8] M. D. Greenhalgh, S. P. Thomas, J. Am. Chem. Soc., 2012, 134, 11900-11903.

[9] G. A. Olah, B. Török, J. P. Joschek, I. Bucsi, P. M. Esteves, G. Rasul, G. K. S. Prakash, J. Am. Chem. Soc., 2002, 124, 11379-11391.

[10] K. Nemoto, H. Yoshida, N. Naoki, N. Morohashi, T. Hattori, J. Org. Chem., 2000, 75, 7855-7862.

[11] E. K. Noh, S. J. Na, S. Sujith, S. W. Kim, B. Y. Lee, J. Am. Chem. Soc., 2007, 129, 8082-8083.

[12] B. Y. Lee, H. Y. Kwon, S. Y. Lee, S. J. Na, S. Han, H. Yun, H. Lee, Y. W. Park, J. Am. Chem. Soc., 2005, 127, 3031-3037.

[13] J. Sun, S. I. Fujita, F. Y. Zhao, M. Arai, Green Chem., 2004, 6, 613-616.

[14] C. M. Byrne, S. D. Allen, E. B. Lobkovsky, G. W. Coates, J. Am. Chem. Soc., 2004, 126, 11404-11405.

[15] R. Johansson, O. F. Wendt, Dalton Trans., 2007, 4, 488-492.

[16] J. L. Song, X. J. Feng, Y. Yamamoto, A. I. Almansour, N. Arumugam, R. Suresh Kumar, M. Bao, Asian J. Org. Chem., 2017, 6, 177-183.

[17] N. Hazari, D. P. Hruszkewycz, J. G. Wu, Synlett, 2011, 13, 1793-1797.

[18] D. P. Hruszkewycz, J. G. Wu, N. Hazari, C. D. Incarvito, J. Am. Chem. Soc., 2011, 133, 3280-3283.

[19] J. G. Wu, N. Hazari, Chem. Commun., 2011, 47, 1069-1071.

[20] H. A. Duong, P. B. Huleatt, Q. W. Tan, E. L. Shuying, Org. Lett., 2013, 15, 4034-4037.

[21] T. Ohishi, M. Nishiura, Z. M. Hou, Angew. Chem. Int. Ed., 2008, 47, 5792-5795.

\section{Graphical Abstract}

Chin. J. Catal., 2018, 39: 1258-1262 doi: 10.1016/S1872-2067(18)63045-1

Carboxylative Suzuki coupling reactions of benzyl chlorides with allyl pinacolborate catalyzed by palladium nanoparticles

Jian Sun*, Jiasheng Wang, Xiujuan Feng*, Yoshinori Yamamoto, Abdulrahman I. Almansour, Natarajan Arumugam, Raju Suresh Kumar, Ming Bao*

Dalian University of Technology, China; Tohoku University, Japan; Ritsumeikan University, Japan; King Saud University, Saudi Arabia

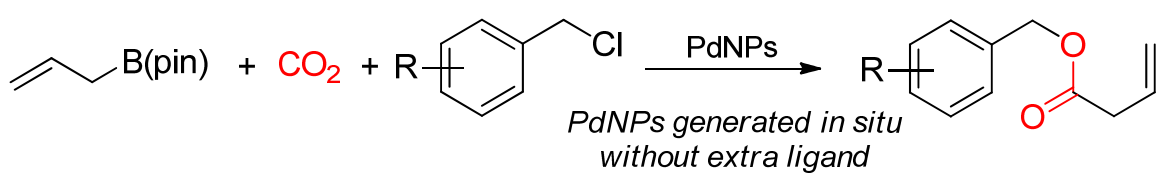

A novel palladium nanoparticles-based catalyst system for carboxylative Suzuki coupling reactions of benzyl chlorides with allyl pinacolborate was developed under mild reaction conditions (low $\mathrm{CO}_{2}$ pressure and temperature) in the absence of any extra ligands. The catalytic system is generated in situ and can thus avoid cumbersome processes for the preparation of metal nanoparticles. 
[22] I. I. F. Boogaerts, G. C. Fortman, M. R. L. Furst, C. S. J. Cazin, S. P. Nolan, Angew. Chem. Int. Ed., 2010, 49, 8674-8677.

[23] L. Zhang, J. H. Cheng, T. Ohishi, Z. M. Hou, Angew. Chem. Int. Ed., 2010, 49, 8670-8673.

[24] W. Z. Zhang, W. J. Li, X. Zhang, H. Zhou, X. B. Lu, Org. Lett., 2010, 12, 4748-4751.

[25] T. Fujihara, T. H. Xu, K. Semba, J. Terao, Y. Tsuji, Angew. Chem. Int. Ed., 2011, 50, 523-527.

[26] L. Zhang, J. H. Cheng, B. Carry, Z. M. Hou, J. Am. Chem. Soc., 2012, 134, 14314-14317.

[27] H. Inomata, K. Ogata, S. Fukuzawa, Z. M. Hou, Org. Lett., 2012, 14, 3986-3989.

[28] X. J. Feng, A. L. Sun, S. Zhang, X. Q. Yu, M. Bao, Org. Lett., 2013, 15,
108-111.

[29] J. Sun, X. J. Feng, Z. R. Zhao, Y. Yamamoto, M. Bao, Tetrahedron, 2014, 70, 7166-7171.

[30] J. Sun, M. Bao, X. J. Feng, X. Q. Yu, Y. Yamamoto, A. I. Almansour, N. Arumugam, R. S. Kumar, Tetrahedron Lett., 2015, 56, 6747-6750.

[31] S. R. Lu, Z. W. Xu, M. Bao, Y. Yamamoto, Angew. Chem. Int. Ed., 2008, 47, 4366-4369.

[32] B. Peng, S. Zhang, X. J. Feng, X. Q. Yu, M. Bao, Org. Lett, 2011, 13, 5402-5405.

[33] M. Bao, H. Nakamura, Y. Yamamoto, J. Am. Chem. Soc., 2001, 123, 759-760.

[34] S. W. Wright, D. L. Hageman, L. D. Mcclure, J. Org. Chem., 1994, 59, 6095-6097.

\title{
纳米钯催化苄基氯代物与烯丙基硼酸频哪醇酯的羧化 Suzuki 偶联反应
}

\author{
孙 健 ${ }^{\mathrm{a}, \$}$, 王加升 ${ }^{\mathrm{a}, \mathrm{b}}$, 冯秀娟 ${ }^{\mathrm{a},{ }^{*}}$, Yoshinori Yamamoto ${ }^{\mathrm{a}, \mathrm{c}, \mathrm{d}}$, Abdulrahman I. Almansour ${ }^{\mathrm{e}}$, \\ Natarajan Arumugam ${ }^{\mathrm{e}}$, Raju Suresh Kumar ${ }^{\mathrm{e}}$, 包 明 a,b,\# \\ ${ }^{\mathrm{a}}$ 大连理工大学精细化工国家重点实验室, 辽宁大连 116023 \\ ${ }^{b}$ 大连理工大学石油与化学工程学院, 辽宁盘锦 124221 \\ ' 东北大学理学研究科化学系, 仙台980-8578, 日本 \\ d立命馆大学科学技术研究所, 草津, 志贺525-8577, 日本

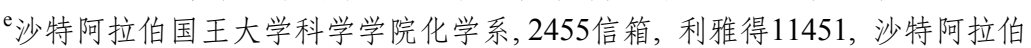

摘要: $\mathrm{CO}_{2}$ 是廉价的 $\mathrm{Cl}$ 源, 同时具有无毒、储量丰富的优点, 符合绿色化学发展要求. 利用 $\mathrm{CO}_{2}$ 构筑新的 $\mathrm{C}-\mathrm{C}$ 键是化学固定 $\mathrm{CO}_{2}$ 的重要方法. $\beta, \gamma$-不饱和酯类结构单元是许多生物活性分子的重要组成部分, 经由双 $\pi$-烯丙基钯中间体与 $\mathrm{CO}_{2}$ 反应, 合 成新的 $\beta, \gamma$-不饱和酯类化合物, 具有重要意义. $\mathrm{CO}_{2}$ 与有机嗍化合物的羧化反应已有报道, 有机硼化合物具有低毒、对水不敏 感等优点. 但是已报道的羒化 Suzuki 偶联反应存在诸多缺点: (1) 需要使用含膦或者氮杂环卡宾配体的催化剂, 而这些催化 剂的制备过程使前期实验步骤变得圥长, 同时反应液的酸化后处理过程也会造成环境污染; (2) 有机硼试剂的官能团兼容 范围窄, 限制了底物范围的拓展. 本课题组以原位生成的纳米钯粒子为催化剂, 在 $\mathrm{CO}_{2}$ 存在的温和条件下, 高效实现了芐氯 与烯丙基嗍酸频哪醇酯的羧化 Suzuki 偶联反应. 反应过程中无其它配体加入, 反应结束后不需要酸化或酯化的后处理过 程. 该反应将具有广泛的官能团兼容性.

本文以 $\mathrm{TBAB}$ 稳定的纳米钯粒子为催化剂, 在温和条件下, 实现了氯甲基芳香化合物、烯丙基硼酸频哪醇酯和 $\mathrm{CO}_{2}$ 的三 组分羧化 Suzuki 偶联反应. 最佳反应条件为: $\operatorname{Pd}(\mathrm{acac})_{2}(5 \mathrm{~mol} \%)$ 、 $\mathrm{TBAB}(0.7 \mathrm{mmol}, 1.4$ equiv. $) 、 \mathrm{KF}(1 \mathrm{mmol}, 2.0$ equiv. $)$ 、苄 基卤代物 $(0.5 \mathrm{mmol})$ 、烯丙基硼酸频哪醇酯 $\left(0.6 \mathrm{mmol}, 1.2\right.$ equiv.)、 $\mathrm{CO}_{2}(2.0 \mathrm{MPa})$ 、溶剂 $\mathrm{THF}(5 \mathrm{~mL}), 50^{\circ} \mathrm{C}$ 反应 $24 \mathrm{~h}$. 在最佳 反应条件下, 苯环、菜环以及杂芳环的氯甲基化合物均可发生该羧化反应. 苯环上取代基的位置对产物的收率有影响. 当使 用 1-澳甲基菜作为底物时反应也能够发生, 收率与 1 -氯甲基菜作为底物时的收率相当. 与已报道有机硼试剂的羧化反应相 比,该反应体系无需加入配体, 原位生成了纳米钯粒子,避免了催化剂或者配体的复杂制备过程. 该反应中,氟离子的存在是 必要的,对烯丙基硼酸频哪醇酯具有活化作用.

关键词: 纳米钯; 羧化 Suzuki 偶联; 二氧化碳; 芐基氯代物; 烯丙基硼酸频哪醇酯

收稿日期: 2017-01-15. 接受日期: 2018-02-05. 出版日期: 2018-07-05.

*通讯联系人. 电话: (0411)84986180; 传真: (0411)84986181; 电子信箱: fengxiujuan@dlut.edu.cn

\#通讯联系人. 电话: (0411)84986180; 传真: (0411)84986181; 电子信箱: mingbao@dlut.edu.cn

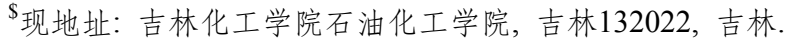

基金来源：国家自然科学基金 (21372035, 21373041, 21773021); 中央高校基本科研业务费专项资金 (DUT17ZD212); 沙特国王大 学国际合作项目 (ISPP\#0048).

本文的电子版全文由Elsevier出版社在ScienceDirect上出版(http://www.sciencedirect.com/science/journal/18722067). 